\title{
Careers of commercially successful female entrepreneurs in context of underdeveloped markets and weak institutions
}

\section{ABSTRACT}

Purpose - Careers have come to dominate contemporary discourse on gendered entrepreneurship. In this paper, we explore entrepreneurial careers as recounted by commercially successful female entrepreneurs to examine how they strategize to construct desirable careers in contexts characterized by underdeveloped markets and weak institutions.

Design/methodology/approach - Using a qualitative research design, data for our inquiry comes from publicly available life-history accounts of twenty female entrepreneurs appearing on an enterprise focus television show in Nigeria. We supplemented our television interview data with archival data in the form of publicly available digital footprints of the entrepreneurs collected from their company websites, magazines, online newspapers featuring these entrepreneurs, and their social media pages such as LinkedIn, Wikipedia, Facebook, and Instagram.

Findings - The careers of female entrepreneurs operating in context of underdeveloped institution and markets, we found, are characterized by four heterogeneous ingrained dispositions and actions reflecting how they got in and got on with their entrepreneurial careers: (a) 'Observing and playing business' (b) traipsing the 'path less travelled' (3) a hook to the 'Pierian spring' of entrepreneurship, and (4) 'grace under pressure' in decision-making.

Originality/value - We contribute to the entrepreneurship literature by providing insight into the lived experiences, agency, and careers of commercially successful female entrepreneurs as played out in the form of a contextual practice of 'wayfinding' to starting up and managing their own business ventures.

Keywords - Commercially successful entrepreneurs, entrepreneurial careers; life-history; lived experiences, underdeveloped markets, weak institutions.

\section{Introduction}

Women as business-owners in the global economy has been mirrored by a proliferation of studies examining female entrepreneurship over the past decades. Female entrepreneurship has now come to represent an important instrument for economic growth as it has a leading role in generating and increasing productivity, achieving gender equality, and reducing poverty (Ojong et al., 2021; Boateng, 2021; Valdivia, 2015). While the contribution of self-employed women tends to be higher than that of men (Chakraborty and Chatterjee, 2021; Minniti and Naude 2010), recent studies suggest that women forming businesses has increased significantly and represent one of the fastest growing segments of the world economy (Gerlach, 2021; McAdam and Cunningham, 2021).

Nevertheless, profuse interdisciplinary literature examining female entrepreneurial career outcomes suggest that the rates of female entrepreneurial activities are significantly and systematically lower than those of males (Jennings and Brush, 2013; Langowitz and Minniti, 2007). Women's business ventures have also been found to perform more poorly than that of their male counterparts (Robb and Watson, 2012; Rocha and Van Praag, 2020; Cabrera and Mauricio, 2017). A plethora of deterministic 
and voluntaristic factors or practices have been noted to impede female entrepreneurial careers. These include pervasive forms of marginalisation associated with gender-role stereotyping (Gupta, 2014), resource access and cost $(\mathrm{Wu}, 2012)$, and the institutional environment within which they operate (Elam and Terjesen, 2010). Often brought into sharp focus are the challenges they face in balancing work and family life, handling patriarchal societal demands on them, and the incessant gender discrimination they encounter in forging their entrepreneurial careers (De Clercq, et al.,2021; Panda, 2018). The result is often a conflict, sandwiched between their roles as entrepreneurs versus family and societal expectations (Bullough et al., 2021), which in turn leads to protracted, precarious, and aften uninspiring female entrepreneurial careers (Hundera et al., 2019). In addition, while the broader female entrepreneurship literature has for some time been preoccupied with the new turn to entrepreneurial careers in general (Zhao et al., 2021; Liñán et al, 2020), relatively little is known about the dynamics of female entrepreneurial careers, their outcomes, and especially how those embedded and operating in countries characterised by weak institutions and underdeveloped markets strategize to construct a desirable career (Liñán et al, 2020; De Vita et al., 2014; Brush and Cooper, 2012).

We argue that understanding what it takes for female entrepreneurs, particularly, those from developing countries to pursue commercially 'successful' entrepreneurial careers could extend our understanding of their mentalities, motivations, and broader socio-cultural challenges they deal with in their everyday situated practice in context characterised by weak institutions and underdeveloped markets (Sun et al., 2020; Welter, 2011). Given the influence of female entrepreneurship on social and economic development (Vracheva and Stoyneva, 2020), such investigation and its outcome could help to develop better evidence-based initiatives, that could help nurture, foster, and cultivate the potentialities of female entrepreneurs and industry captains of the future (Bui et al., 2017). Our objective in this study therefore is to explore how commercially successful female entrepreneurs strategize to construct desirable entrepreneurial careers in contexts characterised by underdeveloped institutions and markets. Employing a life history approach (Dhunpath, 2000), we approach our study through the entrepreneurial life histories recounted by young female entrepreneurs appearing on an enterprise focus television show in Nigeria. Our choice of Nigeria as an empirical research site is reflected in the country's having the highest percentage of entrepreneurs among working-age adults of any continent in the world (Nwagu and Enofe, 2021; Ratten and Jones, 2018). The Global Entrepreneurship Monitor (GEM) in 2013 and 2015 found that irrespective of gender, 82\% of Nigerians could be classified as potential entrepreneurs. Not all, Nigeria double as a developing country with weak institutions and market provides a rich context to studying the entrepreneurial careers of successful female entrepreneurs (Obisesan and Olayide, 2021; Bardasi et al., 2011). 
Our study and its findings therefore make two contributions. First, in explicating the career of female entrepreneurs as played out in the form of 'wayfinding' to creating and capturing opportunities otherwise overlooked by others, we shed light on the lived experiences of commercially successful female entrepreneurs, and their agency to influence their contexts. In this regard, we address the clarion call to expand female entrepreneurship research beyond its usual focus on the opportunities and challenges faced by barefoot female entrepreneurs in developing countries (De Vita et al., 2014; McAdam et al., 2019). Second, by adopting a life history account, we add to the female entrepreneurship literature by providing rare insight into the ways in which commercially successful female entrepreneurs in the developing world make sense of their entrepreneurial careers and lived experiences in narrative terms (Bennett and Dann, 2000). Providing a nuanced perspective on how entrepreneurial careers come to be identified and labelled, we found the career accounts of our entrepreneurs to be characterised by four distinct heterogeneous ingrained dispositions and actions reflecting how they got in and got on with their entrepreneurial careers and highlights opportunities for ecosystem stakeholders that support and promote female entrepreneurs to building business of the future (Nair, 2020; Neumeyer et al., 2019).

The article is structured as follows. In the next section, we review the salient literature on female entrepreneurial careers, after which we explain our research methodology. Following this, we present our research findings and conclude with a discussion of our findings and its implications for the theory and practice of female entrepreneurship.

\section{Female entrepreneurial careers}

An entrepreneurial career is a type of career pursued by people who adopt self-employment by starting up or managing their own business venture (Coetzee and Schreuder, 2016; Ng and Feldman 2014; Chatterjee et al. 2019). A lifelong learning process that is not defined by fixed developmental procedures, an entrepreneurial career as argued by Ivanyshyn et al., (2020) is cultivated through a sequence of events occurring in stages to the aspiring individual proceeding both before and after initiating a new venture with its outcomes frequently measured by venture creation and selfemployment (Costa et al., 2016). Unlike ability, which is evenly distributed among entrepreneurs, opportunities to pursuing entrepreneurial careers for women, over decades, remain stubbornly low and limited (Sullivan and Meek, 2012). Yet entrepreneurial survival and market pressures demand those female entrepreneurs to have prototypical entrepreneurial skills and foresight to creating and capturing sustainable value for their firms (Goffee and Scase, 2015). Beyond everyday organizing challenges, they tend to face the incipient pressure of striking a balance between their social gender roles and improving their overall entrepreneurial career quality (Sorgner, 2015; DeMartino et al., 2006). 
These enduring challenges have triggered revisions in female entrepreneurial career constructions (Rocha and Van Praag, 2020; Braches and Elliott, 2017), because, as boundaryless as they may be, they tend to unfold differently owing to the socio-cultural peculiarities they must navigate when starting, growing, and scaling their ventures (Tur-Porcar, et al., 2016; Duberley and Carrigan, 2013). In this regard, some studies have refocused attention to exploring female entrepreneurial careers as embodied by a unique set of experiences which cumulatively shape the female entrepreneurial approach (Santos et al. 2016; Reaves, 2008). This in many cases have spurred researchers to probing their entrepreneurial competences (Dawa et al, 2021), and preoccupied policymakers to levelling the entrepreneurship 'playing field' so female entrepreneurs can better compete with their male counterparts (Mersha and Sriram, 2019; Kochhar et al., 2017).

An emerging stream of literature has increasingly been preoccupied with issues and challenges female entrepreneurs face in organising and crafting their entrepreneurial careers (Orser, et al, 2012). Against this backdrop, Essers and Benschop (2007) caution that female entrepreneurs must repeatedly prove themselves as capable, and firms owned and run by women frequently experience bias and discrimination in the marketplace (Alsos et al., 2006; Wu and Sirgy, 2014). Such challenges to female entrepreneurial careers as observed by García and Welter (2013) get exacerbated in context characterised by relatively weak institutions and underdeveloped markets, resulting in many women struggling to pursue meaningful entrepreneurial careers (Dy and Marlow, 2017; Brixiová and Kangoye, 2016). The upshot is the low new venture creation reported in these regions (Anderson and Ronteau, 2017) and the making of many 'token' or barefoot female entrepreneurs (Imas and Wilson, 2012), who generally struggle to create and capture what could be described as sustained and meaningful value from their entrepreneurial activities (Wheadon and Duval-Couetil, 2019).

Recently, a major advance within the literature on entrepreneurial careers (See for example: Constantinidis, 2021; Burt, 2019; Martin et al, 2015; VanderBrug, 2013) has tended to focus on extending our understanding of the lived experience of female entrepreneurs, and the context within which they build their careers. Representing an eclectic mix of ideas on 'the where, the when, the who, and the how' gendered entrepreneurial careers play out, this new turn to contextualization (Huang et al, 2020; Welter et al., 2019) promises compelling insight into the diverse lived experiences of female entrepreneurs, and how the context in which they are embedded inform their decision-making regarding their decision to becoming or being an entrepreneur (Calás, et al, 2009). According to this literature, a growing number of female entrepreneurs embedded in highly differentiated contexts, often characterised by weak institutions and market, have become industry captains with many going on to forge what can be described as successful entrepreneurial careers (Javadian and Singh, 2012; Verheul et al., 2001). They emphasise their capacity to coping with conflicting demands (De Clercq et al., 2021), 
and discipline, and trust as some of the salient attributes of those female entrepreneurs who tend to become commercially successful in those contexts (Tlaiss, 2019).

Surprisingly, we know very little about how these new breeds of female entrepreneurs strategize to construct desirable careers (Braches and Elliot, 2017), and how they employ their agency to influence their context (Tlaiss and McAdam, 2021; Zikic and Ezzedeen, 2015). In this regard, we posit that commercially successful female entrepreneurs in developing countries represent an interesting group of entrepreneurs through which to examine successful entrepreneurial careers constructed in contexts characterised by underdeveloped institutions and markets resulting in poor economic opportunities, particularly for young people (Amoako et al., 2021; Moulick et al., 2019). We therefore develop our contribution by drawing on commercially successful female entrepreneurs in Nigeria invited to recount their entrepreneurial careers on contemporary entrepreneurship focused television shows. In what follows, we now explain our research methodology and data analysis.

\section{Research methodology}

\section{Research context}

Nigeria, an emerging economy characterised by underdeveloped market and weak institutions is the entrepreneurial 'Mecca' of Africa (Ratten and Jones, 2018). While successive Global Entrepreneurship Monitor (GEM) reports have lauded the country's entrepreneurial development rate, its state of "hyperentrepreneurship" is borne out of necessity in response to the country's ever-rising unemployment, and lack of institutional support for the poor (Omeje et al., 2020; Hu et al., 2016). Nevertheless, the significance of female entrepreneurs to both the social and economic development of Nigeria is much more instructive. Consistent with GEM reports that $17-41 \%$ of new business in developing economies are set up by females, women accounted for $41 \%$ ownership of micro businesses in Nigeria (Alade, 2020). Their business ventures also appear to thrive well despite having little relational, financial, and knowledge resources required to successfully run and sustain a business in conditions of underdeveloped markets and institutions (Ojong et al., 2021; Ramdani et al, 2015). Despite these tremendous achievements, the literature is only replete with the struggles of barefoot female entrepreneurs operating in context where information is scarce, and uncertainty is intense (Marlow and Martinez, 2018). Following this trend, the literature on female entrepreneurship in Nigeria, for example, has consistently focused on the challenges female entrepreneurs face in creating and capturing value to supporting their families (Nziku and Struthers, 2018). Even in an era where celebrity entrepreneurs are frequently profiled to share their experiences and recount their paths to success to the listening public (Boyle and Kelly, 2010; Curran, 2016), female entrepreneurs in Nigeria are seldom featured in the media as industry captains or potential 'movers and shakers' (Madichie, 2009). In this regard, we 
know very little about the entrepreneurial careers of the new breed of successful female entrepreneurs. In this regard, we argue that commercially successful Nigerian female entrepreneurs represent an interesting research group through which to examine entrepreneurial careers.

\section{Data sources}

We develop our contribution in the context of a popular Nigerian TV show - 'Under40 CEOs', where commercially successful entrepreneurs under the age of 40 are invited to narrate their entrepreneurial careers to the public. Played out in the form of a life-history narrative or what has come to be known as 'time line interviews' (Cederberg and Villares-Varela, 2019; Grabowska, 2018), these entrepreneurs are asked by a TV presenter to reflected on their careers focusing on their life experiences, past socializations, and their motive for starting their individual businesses; they are encouraged to shed light on their business philosophies, challenges they experience in their everyday situated practice as entrepreneurs, as well as the tactics and strategies they frequently adopt to deal with those challenges. Each of these interviews on the show tend to last at least 30 minutes. The TV programme producers have made approximately 70 episodes of the show, featuring different entrepreneurs, publicly available on YouTube, a public video archive available to users on web 2.0.

Owing to our interest in female entrepreneurial careers, we watched the interviews of twenty (20) of the Nigerian female entrepreneurs appearing on this programme, and then transcribed each of the interview into textual data. Table 1.0 provides a summary of the biographical sketch of the entrepreneurs.

\section{Insert Table 1 about here}

Operating diverse ventures ranging from architecture to waste management, all our entrepreneur is had college education. Aged between 23 and 40, the average age of our entrepreneurs is 35.75 years old, with each having an average of 30 employees. In order to help us build a complete biographical sketch of each entrepreneur, get a good understanding of their entrepreneurial journeys and extend our understanding of their lived experiences, we supplemented our main data source, the interviews, with archival data in the form of publicly available digital footprints of the entrepreneurs collected from their company websites, magazines, online newspapers featuring these entrepreneurs, and their social media pages such as LinkedIn, Wikipedia, Facebook, and Instagram (Fisch and Block, 2021; Golder and Macy, 2014). 


\section{Data analysis}

Our data analysis comprised of three main stages. The first involved watching the YouTube videos of our selected entrepreneurs on the media 'stomp' several times to make sure what we transcribed reflected what was heard in the videos. The main analysis then began with the triangulation (Denzin, 2007) of our disparate data sources (the interviews and the digital footprint archival data). Next was the reviewing of the resulting data set and the identification of common descriptive codes tied directly to the words of the entrepreneurs. At this stage, judgements about meanings of contextual statements were made so that the relevance and importance of issues and implicit connections between them could be made (Corley and Gioia, 2004). Following Linde (1993) we tried to identify those narrative accounts that were generally framed around events, behaviours, and the traits which we considered to be crucial for career and entrepreneurial ventures success. We then made cross-references between the events, behaviours, traits, and in some cases, the original video file to capture the tone of voice and corresponding gestures that could guide the judgement process. It was during this phase that the identification of some common themes and patterns that could be coded began to emerge. We listed and continuously reviewed the open codes for patterns and linkages between them. (DiCicco-Bloom and Crabtree, 2006; Guest et al., 2006).

In the second stage, several of the codes developed previously were considered as core codes to be focused on as central to understanding the substantive topic, around which more in-depth analysis and interpretation was concentrated (La Pelle, 2004). Examples of the core category codes developed comprised issues like resilience; passion; enterprise; opportunity recognition; learning; risk; education and foresight. We sought to deepen our interpretation of the relationships between our core categories and ways to explaining why these relationships existed. During this stage, there was a prolonged and systematic search for similarities and differences between our core categories and existing literature on entrepreneurial careers.

In the final stage, selective coding was applied, which aided in further reviewing the categories by examining the relationships between them with the sole aim of integrating, developing, and naming core categories- 'observing and playing business', 'traipsing the 'path less travelled', 'hook to the pierian spring of entrepreneurship', 'grace-under-pressure'. This step permitted the identification of both atypical and typical ideas, which were eventually pulled together into themes to gain a rich, nuanced understanding of the careers of our entrepreneurs. Table 2.0 is a summary of the emerging dimensions, themes, their potential meanings highlighting the becoming of successful entrepreneurial careers, and representative data.

Insert Table 2 about here 
We wish to reflect on our methodological limitation before presenting the details of our research. First, the interviews were not meant for research. In this regard, the interviews may have been heavily edited with some parts, relevant for research, but not meant for public consumption, simply jettisoned (Cohen and Duberley, 2013). Staged for the TV and playing to the cameras' (Boyle and Kelly, 2010), the entrepreneurs may have been encouraged to embellish their stories to make them appear heroic, and potentially touch raw nerves and emotions to get people 'moving'. Finally, care should be taken in generalizing our findings as all our entrepreneurs were college graduates who, by virtue of their education, past socialization, and social class, could be markedly different from other female entrepreneurs in terms of their social capital mobilization potential to pursuing successful entrepreneurial careers (Solano and Rooks, 2018; Yetim, 2008). We now present the fine details of our findings.

\section{On the 'wayfinding' to creating and capturing opportunities}

In exploring the entrepreneurial careers recounted by our commercially successful female entrepreneurs, we focused on how they strategize to construct desirable careers in contexts characterised by underdeveloped markets and weak institutions. Our analysis suggest that the careers of these female entrepreneurs play out in the form of a contextual practice of 'wayfinding' (Sarpong et al, 2013) to starting up, growing, and managing their own business ventures (Coetzee and Schreuder, 2016). Framed around four main themes, we develop in what follows, a meaningful understanding of the ingrained dispositions and actions of our entrepreneurs, reflecting how they got in and got on with their commercially successful entrepreneurial careers. The first is what we refer to as 'observing and playing business', which emphasises how entrepreneurial early childhood experiences influenced our entrepreneurs interest in starting their own business; their traipsing of the 'path less travelled' by taking their own destiny into their hands to chase for opportunities and potentialities in spaces otherwise overlooked by others; a hook to the pierian spring of entrepreneurship, which is all about the entrepreneurial education they received at college and finally, 'grace under pressure' which sheds light on their ability to cope and operate with very little material and relational resources in a context characterised by complexity, ambiguity, and disruption.

\section{'Observing and playing business'}

Early childhood experiences and enterprise-related activities during the formative years of our entrepreneurs can have profound influence on start-up intentions and entrepreneurial careers (Bignotti and le Roux, 2020). Our data evidence suggests that many of our entrepreneurs had the opportunity to 
'observe and play' business in their formative years (Aldrich and Kim, 2007). This early exposure to the world of business, often through their families who happen to run their own businesses lightened their imagination of owning their own businesses in the future and cultivated their entrepreneurial values Zaman et al., 2021; Kirkwood, 2007). Observing closely what their entrepreneurial parents did in their situated practice help them to develop very practical skills like organization, budgeting, and money management (Hopp et al, 2021). Pam spoke about her family's business experience, and how she learned so much about executing and closing deals by taking her mother's customers and clients to see their properties on the market:

My mum had so many lands, and properties. We used to go with her to transact business and showed prospective buyers around. Growing up into these things mean you'll be able to be your own boss. It gave me the confidence to start on my own.

She went on to argue that conversations around the dinner table with her parents helped her to develop a sound commercial awareness and got her to start thinking about starting her own business. As recounted by our entrepreneurs, their often-significant exposure to enterprise activities during their childhood is what jumpstarted their entrepreneurial careers (Zaman et al, 2021). The case of Beatrice was instructive as she spoke about how her mother's career provided her exposure and self-efficacy to starting her firm:

My mom was a public relation (PR) professional, and worked as marketing manager for Nigeria Airways so, I've just been in the world of PR at a young age. I did some adverts as well for Nigeria Airways. Our house was full of celebrities at the time when we were young. I am my mother's child and I guess that is why it's the only thing I really know how to do. Well, they say an apple doesn't fall too far from the tree, isn't it?

At first glance, it appears that the context within which Beatrice grew up may not have given her insight into alternative careers. However, like the other entrepreneurs who found themselves in a similar situation, her positive view about her family's business experience, we found, significantly shaped her take on starting her own business as both desirable and feasible. At best such exposure, we found, enhanced the psychological safety of our entrepreneurs to experiment with business ideas at an early age within the safety of their home environment (Miao et al., 2019). In a similar development, Laura painted a vivid picture of how family friends in the entertainment industry scouted and supported her to the point where she was self-sufficient to start her own venture:

I had a family friend in my neighbourhood who was then a supermodel so me and said, you're a very perfect person for modelling, have you ever thought about that? He had a meeting with my mum to discuss it and eventually she agreed I could go and try on condition that he would supervise me and if anything went wrong, he would be held responsible.

Emphasising the disposition of our entrepreneurs to relying on family and friends to getting new ideas, support, or inspiration to starting and managing their ventures (Dahl and Sorenson, 2009), Laura went 
further to say her parents, and family-friends have been her biggest champions, giving her the confidence and belief, she needed to take that leap of faith to go into modelling, which surprisingly, opened many opportunities for her.

\section{Traipsing the 'path less travelled'}

Traipsing the "path less travelled" as used in organizing our findings refers to our entrepreneurs' incipient disposition to exploring new potentialities, possibilities, and opportunities to developing products and services to fill taken-for-granted market voids. Played out in the form of an obsession to fulfilling the need of customers and enhancing the capabilities of their communities' (Harmeling, 2011), this pervasive entrepreneurial disposition, we found, is driven by the increasingly prominent new turn to what Dawson (2021) refers to as 'be your own boss', that is changing how many budding female entrepreneurs see the world, with many following their dreams to start new ventures against all odds (Byrne, et al., 2019; Coughlin et al., 2002). Mia describes how she quit her 9am to 5pm job as a banker to pursue her entrepreneurial passion and eventually start up several businesses:

banking was good for me at the time, but I knew there was more I could do beyond the banking hall, but I wasn't sure as to when to leave but when the time came to take that quantum leap, as difficult as it was, I knew that I had to do what I had to do.

Similarly, Amelia described how leaving formal employment to pursue a passion, explaining how the love she has for her career makes a difference in how much dedication, productivity, and consistency she puts into it:

I don't mind working for someone. I enjoy it, but I wanted a job that could make me a lot more money but also something that was much more fulfilling. I couldn't find that, so I wasn't waking up every day with a smile on my face so, I decided to start my own thing.

This credo of people quitting their jobs to pursue entrepreneurship (Chung, 2021), we found, convey the potential for progress based on perseverance and people having a clear sense of their own capabilities, limits, and potentialities. But it has a common thread: having contrarian views about the future, and the temerity to shrug off the patriarchal systems in which our entrepreneurs are embedded and operate (Bui et al., 2018). The case of Winnie who defied her teachers and mentors' entrenched perspectives on what she should study, to pursue a vocational degree in fashion entrepreneurship, exemplifies the 'having a nothing to lose mentality' characterising the desire of our entrepreneurs to taking the road less travelled

I started really discovering myself. I felt I had an incipient passion for fashion, so, I just ignored what everyone was saying to me. May felt it was simply difficult, so I decided I'm going to do a Master of Science (MSc) in Fashion Entrepreneurship (Winnie). 
Conveying and reinforcing the potential for progress through the apparent rejection of received wisdom and entrenched perspectives, Pam underlined the primacy of defying the patriarchal system in which our female entrepreneurs operate:

Trust me, most of us won't even make it in this business if we are not diehards. We wouldn't survive in this very difficult Nigeria if we didn't have that 'I won't give up spirit'. I don't have anybody helping me. My talent is helping me, my talent is sufficient...It was with all my work I got myself there, I had work for it, I had to sweat for it (Pam).

In embracing the challenges inherent in her environment, Pam like many of the female entrepreneurs we studied had to wrangle with the weak institutions that cumulatively undermined their efforts. For this crop of entrepreneurs, navigating their way in this environment, was all about committing themselves to pursuing "a new vision and new ways of doing things" (Cornelissen, 2013: 700), and working for the futures they resolved to set out to create, and own for themselves - a real 'longing for the road not frequently taken by many of their others.

\section{A hook to the 'pierian spring' of entrepreneurship}

Many of the entrepreneurs we studied recounted how they came to realise their latent flair for enterprise (Packham et al., 2010), and ultimately their interest in starting their own ventures after taking enterprise related courses or modules at college (Westhead and Solesvik, 2016). Paralleling a 'taste and subsequent hook' to drinking the 'pierian spring' (Moira, 2002), we label these accounts as a taste of the 'pierian spring' of enterprise as a means for us to selectively extract how these experiences profoundly contributed to the careers of our entrepreneurs. Emma, recounted how the chance to study an entrepreneurship module lightened her imagination to turn her 'passion into money':

I didn't know I wanted to be an entrepreneur.......and then I went into university, and I discovered entrepreneurship, I did a minor in entrepreneurship, and I realised I could turn my passion into you know profit and then I went on that journey.

Emphasizing a strong positive emotional arousal with enterprise, Emma's entrepreneurial career, as revealed by the above extract, we argue, sprang in large measure from the entrepreneurship education she received. The experiences of Grace and Sophia who both decided to go for postgraduate studies to shore up their entrepreneurial skills and know how, and start-up their own venture is instructive.

I studied economics, and it's really been that area that I've focused my career in for the most part, so but while in university of Lagos after studying economics I just thought, you know what economics is a very sort of versatile course to study I thought it would $\mathrm{d}$ be best to add a layer of another degree you know to that, so I then did the exam for the stockbroking Institute in Nigeria and qualified and so that has pretty much been where I've found myself in the last ten years (Grace).

What I realised at university was that I wanted to go much deeper into business I didn't want to just stay at a sort of surface level with regards to being pigeon-holed to only working in fashion. 
I wanted to be able to work with small and big businesses alike, so actually the experience that university reinforced my belief that at some point in my career it would be wise to go back to school to study business that was in 2009, I eventually did my MBA in 2015, an interesting springboard, and it just opened my eyes to many possibilities (Sophia).

Like many of the entrepreneurs in our study, Grace was emphatic she had never thought of starting her own business until she got introduced to entrepreneurship module at college. In this regard, our data evidence points to entrepreneurship education as a primary means through which many of our female entrepreneurs actively fashion out their careers (Ahmed, et al, 2020; Wei et al., 2019). The learning they do on these modules, we surmise, cast as contextualized enterprise education, does not simply prioritises acquiring functional knowledge. It also emphasises practice, understanding what works, and realising what can be done (Penaluna and Penaluna, 2009). This learning is applied to recognising and acting on opportunities towards starting and managing new ventures (Rae, 2000). Thus, having tasted the pierian spring of entrepreneurship, our entrepreneurs learnt a bit more about what they can become, who they want to be and work towards enacting their storied identity (Carey and Matlay2011).

\section{'Grace under pressure' in decision making}

In organizing our findings, we employ Ernest Hemmingway's metaphorical use of courage- 'Grace under pressure' (Lopez et al., 2003), to refer to the everyday courageous actions, and embodied adaptive behaviours exemplified by our entrepreneurs in making salient decisions that gave form to their entrepreneurial careers. This organizing capability, we found is shaped by two countervailing forces: adverse business environment and adaptive behaviour. The poor business environment in which these women operate, constitutively impede their potential to create and capture sustainable value (Rosca et al., 2020), but also drives their often-polyphonic expression of entrepreneurial purpose, in which they seek to articulate courage and adaptive actions to staying the course of the entrepreneurial journey (Garcia-Lorenzo, et al., 2021). Mia reflected on the institutional weakness she had to overcome as a business owner in Nigeria:

Believe me, I'm speaking on behalf of many business owners; we sometimes feel that rather than supporting us the government's strangling our businesses quite frankly and that has been a major challenge. $\mathrm{We}^{\prime}$ ve not really gotten any reasonable explanation.

What we see here is that the business environment represents an adversity and a challenge to value creation and capture; that of our entrepreneurs is to mobilise the necessary courage to triumph over the adversity. Elsewhere, Fran spoke expressly on the adaptability of Nigerian female entrepreneurs and emphasised how the state of institutional weakness offered unique challenges but also help build resilience, and arms the entrepreneurs to pursue their career: 
We are in a race to succeed being in a race with millions of people with the same goal and destination in mind you've just got to rethink your vision, refine your purpose right, know if the pursuit or the chase is worth it. I don't want to mention all the things we know about not having support from the banks, etc. For me, those are cliches. What that has produced in the average Nigerian is the resolve to succeed, and so if one can succeed in the city of Lagos, then I don't see why one will not be able to succeed elsewhere.

The courage to succeed as finely articulated by Fran, we found, is not only necessary to starting a venture. It is ultimately imperative to making everyday decisions aimed at thriving and surviving in such complex circumstances (Duchek, 2018; Bullough et al., 2013). Courage as played out in these adaptive behaviours may play out in solving problems, driving entrepreneurs to persist in the face of setbacks and failures, and to committing the necessary effort to make their ventures succeed (Klyver et al., 2017; Duchek, 2018). As succinctly put by Amelia, courage for our entrepreneurs is also about taking moderate and calculated risk, and knowing when to make deliberative choices aimed at a fine or noble end:

We don't take as much risks as men do that is probably why I am not too quick to open-up my business to investors. I will do that, but I need to grow the business a little more.

Also embodied in the adaptive behaviours reported by our entrepreneurs is their propensity to overcoming their failures and responding appropriately to trials and adversities in their lives (Bullough et al., 2013; Klyver, et al., 2017). Rose who lost her sister because of the slow response of medical aid, decided to pursue a career that would allow her to directly assist people with medical aid:

I really wanted to focus on something more public health, where I could change or be part of the change in our health care system, and hopefully avoid another family having to go through what we went through.

Beyond the differential circumstances within which our entrepreneurs need to act courageously, their account appears bounded together by the necessity to overcome often profound, and gendered contextspecific losses, risks, and significant uncertainties to starting, managing, and growing their ventures (Ward et al., 2019). The upshot of this is our entrepreneurs ability to engage in second-order learning and coping (Pérez-López et al., 2019) with the fleeting and demanding challenges they faced in their everyday organizing, and their broader entrepreneurial careers.

\section{Discussion and conclusion}

In this paper, we explored the entrepreneurial careers of commercially successful entrepreneurs by examining their lived experiences and how they strategize to construct desirable careers in contexts characterised by underdeveloped institutions and frequent environmental shifts. Empirically we draw on the life history accounts of female entrepreneurs appearing on an enterprise focus television show in Nigeria. Emphasizing entrepreneurial careers as wayfinding enacted through distinct temporal 
frames to creating and capturing opportunities otherwise overlooked by others (Chia, 2017; Waddock, and Steckler, 2016), we found explanations on how these entrepreneurs got in and got on with their entrepreneurial careers to be characterised by four heterogeneous ingrained dispositions and actions across space and time. As shown in figure 1, the outer circle with a dotted line covering the ingrained dispositions and actions represents temporality and the centrality of time in the narratives of our female entrepreneurs and the dynamic nature of the sensemaking processes regarding their entrepreneurial careers (De Vos, et al., 2021).

\section{Insert Figure 2 about here}

First, individuals who had prior entrepreneurial exposure, such as entrepreneurial parents, mentors, or prior work experience, had enthused entrepreneurial intention facilitated by desirability and feasibility towards starting a business. This early year's exposure to entrepreneurship shaped a greater awareness and positive attitudes towards entrepreneurship. These entrepreneurs who 'longed for the road not taken' were found to possess an intense devotion and hunger towards entrepreneurship. Not all, these entrepreneurs appear to be relentlessly on the move, being innovative and creating new opportunities to proffer solutions and ideas into the market. This passion reinforced their self-efficacy and positively impacted their career development. A taste of what we refer to as the 'Pierian spring' of entrepreneurship suggest that exposure to entrepreneurial education and entrepreneurial learning nurtured their entrepreneurial intention and self-efficacy, which ultimately ignited their interest in starting their own ventures. The knowledge gained from these entrepreneurial courses essentially facilitated their ability to recognise opportunities otherwise overlooked by others and helped them in managing, growing, and scaling their business through various capital financing strategies. These entrepreneurs, we also found, demonstrated what we refer to as 'grace under pressure' in pursuit of high-growth entrepreneurship and use their agency to influence their difficult to navigate operational contexts. They had to make hard choices in creating and capturing sustainable value in economically challenged locales and stayed the course without abandoning their call when crisis strike their entrepreneurial visions. Such civil courage, we argue helped our entrepreneurs to triumph over the adversities they faced in pursuing and succeeding in their entrepreneurial careers.

Our study has some implication for the theory of female entrepreneurial careers. First, in response to calls for more research on central role of gender stereotypes in explaining (un)successful female entrepreneurial careers (Tlaiss and McAdam, 2021; Verheul et al.,2006), our study unmasks overlooked aspects of successful female entrepreneurial careers, reconceptualises what constitute career success (Gunz and Heslin, 2005), and provide a cause to rethink why some female entrepreneurs may be more 'successful' than others. Second, while previous scholarship has emphasised the 
challenges female entrepreneurs face in developing their entrepreneurial careers (Brixiová and Kangoye, 2016), our study which draws on a life history approach provokes connections between the profiles of our female entrepreneurs and entrepreneurs in other times, and places characterised by underdeveloped markets and institutions (De Vita et al., 2014). Thus, our study shed light on instructive connections with other individual cases and the broader subject of female entrepreneurial career construction and opportunity structures (Cohen and Duberly, 2021; Ozasir Kacar and Essers, 2019). In this regard, we follow Cornelissen (2013: 701) to argue that comparison between our life-history accounts of entrepreneurial careers and what we currently assume about the entrepreneurial process directs our attention to potentially new ways to theorizing female entrepreneurship. Not all, our emphasis on commercially successful entrepreneurs operating in context of underdeveloped markets and institutions opens opportunities to explore the lived experiences of a 'seen but unnoticed' group of female entrepreneurs who are writing their own stories, and how the social, economic, and cultural context shape the making of female entrepreneurs and industry captains of the future.

Our research also has some implication for practice. First, beyond emphasizing the virtues and careers of successful female entrepreneurs, our study and its findings shine a beacon on the path others could follow in crafting their entrepreneurial careers. In this regard, it provides context to (re)orienting the perspectives of budding female entrepreneurs on how they could potentially craft their entrepreneurial careers (Tlaiss, 2019), and gives an indication of what might happen when some of the everyday practices of these entrepreneurs are replicated for others. Second, a potential female entrepreneur, for example, we argue can aspire to be what they know exist. In unpacking how successful female entrepreneurs craft their careers, our study provides opportunities for practicing female entrepreneurs to understanding the intricacies of other's career. Such insight into how some successful female entrepreneurs approached their entrepreneurial careers, their precision and determination, and the values they lived by, provides multiple reference points from which others could emulate or shape their own careers. In simple terms the stories of these entrepreneurs could help sustain the aspirations, dreams, and ambitions for the many talented female entrepreneurs who find themselves embedded in, and operating in contexts marked by patriarchy, and underdeveloped markets and institutions.

While this paper has offered some insights into the gendered entrepreneurship careers of women operating in context of underdeveloped markets and institutions, there are several limitations which in turn provides opportunities for future research. First, in analysing the narrative accounts of twenty commercially 'successful' female entrepreneurs to explore how female entrepreneurs craft their careers, we appear to be "privileging the voices of a particular group of women entrepreneurs" (Byrne et al, 2019). In this regard, our findings may not be generalizable to the larger population of women 
entrepreneurs operating in contexts marked by underdevelopment and weak institutions. Again, the generation of our dataset, from publicly available interviews from a television show, which although may be creative and innovative also has limitations. The participants who are carefully selected to be on this television show are likely to be groomed and prepared to posit their stories in a way that produces suitable content for television. In short, since the interviews are not for research purposes, vital information, which could have provided a richer, clearer insight into the study may have been left out. There is therefore the need for studies of entrepreneurial career development in varying contexts and examining the research results on a more extensive, less heterogeneous sample set of entrepreneurs; suggesting more dynamic behavioural constructs to analyse and discover new themes and implications for successful career development.

In concluding, we hope our study do not just highlight the new reality suggesting that females make up a sizeable portion of the new breed of commercially successful African entrepreneurs. Many of them who would have had their entrepreneurial careers once flattened by the countervailing forces induced by weaker institutions and underdeveloped markets are determined to put their shoulders to the task of crafting successful entrepreneurial careers.

\section{References}

Ahmed, T., Chandran, V.G.R., Klobas, J.E., Liñán, F. and Kokkalis, P. (2020), “Entrepreneurship education programmes: How learning, inspiration and resources affect intentions for new venture creation in a developing economy" International Journal of Management Education, Vol. 18 No.1, p.100327. https://doi.org/10.1016/j.ijme.2019.100327

Alade, B (2020), “' $41 \%$ of Nigeria's micro-businesses owned by women"” Business News, available at: https://guardian.ng/business-services/41-of-nigerias-micro-businesses-owned-by-women/ (accessed 05 October 2021).

Aldrich, H.E. and Kim, P.H. (2007), "A life course perspective on occupational inheritance: Selfemployed parents and their children", In The sociology of entrepreneurship. Emerald Group Publishing Limited.

Alsos, G.A., Isaksen, E.J. and Ljunggren, E. (2006), “New venture financing and subsequent business growth in men-and women-led businesses", Entrepreneurship Theory and Practice, Vol. 30 No. pp.667- 686.

Amoako, I.O., Akwei, C. and Damoah, I. (2021), "We Know Their House, Family, and Workplace": Trust in entrepreneurs' trade credit relationships in weak institutions", Journal of Small Business Management, pp.1-30. doi.org/10.1111/jsbm.12488

Anderson, A. and Ronteau, S. (2017), "Towards an entrepreneurial theory of practice; emerging ideas for emerging economies", Journal of Entrepreneurship in Emerging Economies, Vol. 9 No. 2, pp. 110-120.

Bardasi, E., Sabarwal, S. and Terrell, K. (2011), "How do female entrepreneurs perform? Evidence from three developing regions", Small Business Economics, Vol. 37 No. 4, pp.417-441. 
Bennett, R. and Dann, S. (2000), "The changing experience of Australian female entrepreneurs, Gender, Work \& Organization, Vol. 7 No. 2, pp.75-83.

Bignotti, A. and le Roux, I. (2020), "Which types of experience matter? The role of prior start-up experiences and work experience in fostering youth entrepreneurial intentions", International Journal of Entrepreneurial Behavior \& Research, Vol. 26 No. 6, pp. 1181-1198.

Boateng, D.A. (2021), "Pathways for the economic empowerment of female entrepreneurs in emerging economies: Implications for social work", International Social Work, Vol. 64 No.2, pp.216-232.

Boyle, R. and Kelly, L.W. (2010)," The celebrity entrepreneur on television: profile, politics and power", Celebrity Studies, Vol. 1 No. 3, pp.334-350.

Braches, B. and Elliott, C. (2017), “Articulating the entrepreneurship career: A study of German women entrepreneurs" International Small Business Journal, Vol 35 No. 5, pp.535-557.

Brush, C.G. and Cooper, S.Y., (2012), "Female entrepreneurship and economic development: An international perspective", Entrepreneurship \& Regional Development, Vol. 24 No. 1-2, pp.1-6.

Bui, H.T., Kuan, A. and Chu, T.T. (2018), "Female entrepreneurship in patriarchal society: motivation and challenges", Journal of Small Business \& Entrepreneurship, Vol. 30 No.4, pp.325-343.

Bullough, A., Guelich, U., Manolova, T.S. and Schjoedt, L. (2021), “Women's entrepreneurship and culture: gender role expectations and identities, societal culture, and the entrepreneurial environment", Small Business Economics, pp.1-12. https://doi.org/10.1007/s11187-020-00429-6

Bullough, A., Renko, M. and AbdelZaher, D. (2013), “Women's entrepreneurship: Operating within the context of institutional and in-group collectivism. In Academy of Management Proceedings (Vol. 2013, No. 1, p. 12047). Briarcliff Manor, NY 10510: Academy of Management.

Burt, R.S. (2019), “The networks and success of female entrepreneurs in China”, Social Networks, Vol 58, pp.37-49.

Byrne, J., Fattoum, S. and Diaz Garcia, M. C. (2019), "Role models and women entrepreneurs: entrepreneurial superwoman has her say, Journal of Small Business Management, Vol. 57 No.1, pp.154-184.

Cabrera, E.M. and Mauricio, D., (2017), “Factors affecting the success of women's entrepreneurship: a review of literature" International Journal of Gender and Entrepreneurship. Vol. 9 No. 1, pp. 31-65.

Calás, M., Smircich, L. and Bourne, K. (2009), "Extending the Boundaries: Reframing "Entrepreneurship as social change" through feminist perspectives. Academy of Management Review, 34(3), pp.552-569.

Carey, C. and Matlay, H. (201), "Emergent issues in enterprise education: The educator's perspective", Industry and Higher Education, Vol. 25 No. 6, pp.441-450.

Cederberg, M, Villares-Varela, M. (2019), "Ethnic entrepreneurship and the question of agency: the role of different forms of capital, and the relevance of social class". Journal of Ethnic and Migration Studies 45(1): 115-132.

Chakraborty, S., \& Chatterjee, P. (2021), “Women Entrepreneurs in India: Where Do They Stand?" Indian Journal of Labour Economics, pp.1-24.

Chatterjee, D., Ford, J.K., Rojewski, J. and Watts, S.W. (2019), "Exploring the impact of formal internships on biomedical graduate and postgraduate careers: An interview study", CBE-Life Sciences Education, Vol. 18 No.2, pp.1-13. doi.org/10.1187/cbe.18-09-0199. 
Chia, R. (2017), "A process-philosophical understanding of organizational learning as "wayfinding": Process, practices and sensitivity to environmental affordances", The Learning Organization, Vol. 24 No. 2, pp. 107-118.

Chung, D. (2021), “Quitting Your Job to Pursue Entrepreneurship or Join Start-ups: Implications on Job Satisfaction". In Academy of Management Proceedings (Vol. 2021, No. 1, p. 12603). Briarcliff Manor, NY 10510: Academy of Management.

Cohen, L., and Duberley, J. (2021), “Making Sense of Our Working Lives: The concept of the career imagination", Organization Theory, Vol. 2 No. 2, 26317877211004600. https://doi.org/10.1177/26317877211004600

Cohen, L. and Duberley, J. (2013), “Constructing careers through narrative and music: An analysis of Desert Island Discs", Journal of Vocational Behavior, Vol. 82 No. 3, pp.165-175.

Constantinidis, C. (2021), "How female entrepreneurs build strong business relationships: the power of gender stereotypes", International Journal of Gender and Entrepreneurship, Vol. ahead-ofprint No. ahead-of-print

Cornelissen, J.P. (2013), "Portrait of an entrepreneur: Vincent van Gogh, Steve Jobs, and the entrepreneurial imagination." Academy of Management Review, Vol. 38 No. 4, 700-709.

Coughlin, J.H. and Thomas, A.R. (2002), The rise of women entrepreneurs: People, processes, and global trends. Greenwood Publishing Group.

Curran, K. (2016), "The Evolution of Celebrity Entrepreneurs". In Academy of Management Proceedings (Vol. 2016, No. 1, p. 16901). Briarcliff Manor, NY 10510: Academy of Management.

Dahl, M.S. and Sorenson, O. (2009), "The embedded entrepreneur", European Management Review, Vol. 6 No.3, pp.172-181

Dawa, S., Namatovu, R., Mulira, F., Kyejjusa, S., Arinaitwe, M. and Arinaitwe, A. (2021), "Entrepreneurial competences and growth of female-owned enterprises: the mediation role of absorptive capacity", International Journal of Gender and Entrepreneurship, Vol. 13 No. 1, pp. 3049.

Dawson, H. J. (2021), “'Be Your Own Boss': Entrepreneurial Dreams on the Urban Margins of South Africa." In Beyond the Wage: Ordinary Work in Diverse Economies, edited by W. Monteith, O. Vicol, and P. Williams, 115-138. Bristol: Bristol University Press.

De Clercq, D., Brieger, S.A. and Welzel, C., (2021), "Leveraging the macro-level environment to balance work and life: an analysis of female entrepreneurs' job satisfaction", Small Business Economics Vol. 56 No.4, pp.1361-1384.

De Vita, L., Mari, M. and Poggesi, S. (2014), “Women entrepreneurs in and from developing countries: Evidence from the literature. European Management Journal, Vol. 32 No. 3, pp.451-460.

De Vos, A., Jacobs, S. and Verbruggen, M. (2021), "Career transitions and employability", Journal of Vocational Behavior, 126, p.103475. https://doi.org/10.1016/j.jvb.2020.103475

DeMartino, R., Barbato, R. and Jacques, P.H. (2006), “Exploring the career/achievement and personal life orientation differences between entrepreneurs and nonentrepreneurs: The impact of sex and dependents, Journal of Small Business Management, Vol. 44 No.3, pp.350-368.

Dhunpath, R. (2000), "Life history methodology: "narradigm" regained", Qualitative Studies in Education, Vol.13 No.5, pp.543-551. 
DiCicco-Bloom, B. and Crabtree, B.F. (2006), "The qualitative research interview", Medical Education, Vol. 40 No. 4, pp.314-321.

Dino, R.N. (2015), “Crossing boundaries: Toward integrating creativity, innovation, and entrepreneurship research through practice," Psychology of Aesthetics, Creativity, and the Arts, Vol. 9 No. 2, p.139.

Duberley, J. and Carrigan, M. (2013), “The career identities of 'mumpreneurs': Women's experiences of combining enterprise and motherhood", International Small Business Journal, Vol.31 No.6 pp.629-651.

Duchek, S. (2018), "Entrepreneurial resilience: a biographical analysis of successful entrepreneurs, International Entrepreneurship and Management Journal, Vol. 14 No. 2, pp.429-455.

Dyer Jr, W. G (1995),"Toward a theory of entrepreneurial careers." Entrepreneurship Theory and Practice, Vol. 19 No. 2, pp. 7-21.

Dy, A.M. and Marlow, S. (2017), "Women entrepreneurs and their ventures: complicating categories and contextualising gender". In The Routledge companion to global female entrepreneurship (pp. 15-29). Routledge.

Elam, A. and Terjesen, S. (2010)," Gendered institutions and cross-national patterns of business creation for men and women", European Journal of Development Research, Vol. 22No. 3, pp.331-348.

Essers, C. and Benschop, Y. (2007), "Enterprising identities: Female entrepreneurs of Moroccan or Turkish origin in the Netherlands", Organization Studies Vol. 28 No.1, pp.49-69

Fisch, C. and Block, J.H. (2021), "How does entrepreneurial failure change an entrepreneur's digital identity? Evidence from Twitter data", Journal of Business Venturing, Vol. 36 No.1, p.106015.

Garcia-Lorenzo, L., Jalan, I. and Sheikh, N. (2021), “The 'Entreprenoorial'Journey: Exploring the Liminal Identity transitions of Female Entrepreneurs", Academy of Management Proceedings (Vol. 2021, No. 1, p. 11864). Briarcliff Manor, NY 10510: Academy of Management.

García, M. and Welter, F. (2013), “Gender identities and practices: Interpreting women entrepreneurs' narratives", International Small Business Journal Vol. 31 No.4 pp.384-404.

Gerlach, M. D. (2021), “Female Social Entrepreneurship: Challenging boundaries and reframing gender and economic structures". Verlag Barbara Budrich.

Golder, S.A. and Macy, M.W. (2014) “Digital footprints: Opportunities and challenges for online social research", Annual Review of Sociology, Vol. 40, pp.129-152.

Goffee, R., \& Scase, R. (2015), “Women in charge (Routledge revivals): The experiences of female entrepreneurs", Routledge, London.

Grabowska, I (2018), "Social skills, workplaces, and social remittances: a case of post-accession migrants", Work, Employment and Society Vol 32 No. 5, pp.868-886.

Gielnik, M.M., Bledow, R. and Stark, M.S. (2020), "A dynamic account of self-efficacy in entrepreneurship", Journal of Applied Psychology, Vol. 105 No.5, pp. 487-505.

Guest, G., Bunce, A. and Johnson, L. (2006), “How many interviews are enough? An experiment with data saturation and variability", Field Methods, Vol. 18 No.1, pp.59-82.

Gupta, V.A. (2014), “Gender differences in evaluation of new business opportunity: a stereotype threat perspective", Journal of Business Venturing, Vol. 29, pp. 273-288. 
Gunz, H.P. and Heslin, P.A., (2005), “Reconceptualizing career success. Journal of Organizational Behaviour, Vol. 26 No.2, pp.105-111.

Harmeling, S. (2011), "Contingency as an entrepreneurial resource: How private obsession fulfills public need", Journal of Business Venturing, Vol.26 No.3, pp.293-305.

Hopp, C., Minarikova, D. and Speil, A. (2019), "A chip off the old block? How parent-child interactions affect the intergenerational transmission of entrepreneurial intentions", Journal of Business Venturing Insights, Vol. 11, p.e00130. https://doi.org/10.1016/j.jbvi.2019.e00130

Hu, Y., Pratt, C.B., Adamolekun, W. and Ogedengbe, A.R. (2016), “Communicating development'-a cultural shift: emerging discourses on entrepreneurial development and poverty reduction by Nigeria's banking and microfinance sectors", Critical Arts Vol.30 No.5, pp.709-727.

Huang, Q., Liu, X. and Li, J. (2020), “Contextualization of Chinese entrepreneurship research: an overview and some future research directions. Entrepreneurship \& Regional Development, Vol. 32 No.5-6, pp.353-369.

Imas, J. M., Wilson, N., \& Weston, A. (2012), “Barefoot entrepreneurs”, Organization, Vol. 19 No.5, pp. 563-585.

Javadian, G. and Singh, R.P. (2012), "Examining successful Iranian women entrepreneurs: an exploratory study", Gender in Management, Vol. 27 No. 3, pp. 148-164.

Jennings, J.E. and Brush, C.G. (2013), "Research on women entrepreneurs: challenges to (and from) the broader entrepreneurship literature? Academy of Management Annals, Vol.7 No.1, pp. 1-69.

Kirkwood, J. (2007), "Igniting the entrepreneurial spirit: is the role parents play gendered?", International Journal of Entrepreneurial Behavior \& Research, Vol. 13 No. 1, pp. $39-59$

Klyver, K., Honig, B. and Steffens, P. (2018), "Social support timing and persistence in nascent entrepreneurship: exploring when instrumental and emotional support is most effective". Vol. 51 No.3, 709-734.

Kochhar, M.K., Jain-Chandra, M.S. and Newiak, M.M. (2017), “Women, work, and economic growth: levelling the playing field", International Monetary Fund, Washington DC.

La Pelle, N. (2004), "Simplifying qualitative data analysis using general purpose software tools", Field Methods, Vol.16 No.1, pp.85-108.

Liñán, F., Jaén, I. and Martin, D. (2020), “Does entrepreneurship fit her? Women entrepreneurs, genderrole orientation, and entrepreneurial culture", Small Business Economics, pp.1-21. doi.org/10.1007/s11187-020-00433-w

Liñán, F., Jaén, I. and Martin, D. (2020), “Does entrepreneurship fit her? Women entrepreneurs, genderrole orientation, and entrepreneurial culture", Small Business Economics, pp.1-21. https://doi.org/10.1007/s11187-020-00433-w

Linde, C. (1993). Life Stories. New York. Oxford: Oxford University Press.

Lopez, S. J., O'Byrne, K. K. and Petersen, S. (2003), “Profiling courage". In S. J. Lopez \& C. R. Snyder (Eds.), Positive psychological assessment: A handbook of models and measures, American Washington DC: Psychological Association, pp. 185-197.

Madichie, N.O. (2009), "Breaking the glass ceiling in Nigeria: A review of women's entrepreneurship", Journal of African Business, Vol. 10 No.1, pp.51-66. 
Martin, L., Wright, L., Beaven, Z. and Matlay, H. (2015), "An unusual job for a woman? Female entrepreneurs in scientific, engineering and technology sectors", International Journal of Entrepreneurial Behavior \& Research, Vol. 21 No. 4, pp. 539-556.

Marlow, S., \& Martinez Dy, A. (2018), "Annual review article: Is it time to rethink the gender agenda in entrepreneurship research?" International Small Business Journal, Vol 36 No.1, pp. 3-22.

McAdam, M. and Cunningham, J.A. (2021), “Women and Global Entrepreneurship: Contextualising Everyday Experiences," Routledge, London.

McAdam, M., Crowley, C., and Harrison, R.T. (2019), “To boldly go where no [man] has gone before"Institutional voids and the development of women's digital entrepreneurship", Technological Forecasting and Social Change, Vol.146, pp.912-922.

Mersha, T., \& Sriram, V. (2019), “Gender, entrepreneurial characteristics, and success: Evidence from Ethiopia", Thunderbird International Business Review, Vol. 61 No.2, pp.157-167.

Miao, Q., Eva, N., Newman, A. and Cooper, B. (2019), “Ceo entrepreneurial leadership and performance outcomes of top management teams in entrepreneurial ventures: The mediating effects of psychological safety", Journal of Small Business Management, Vol. 57 No.3, pp.11191135.

Minniti, M., and Naudé, W. (2010), “What do we know about the patterns and determinants of female entrepreneurship across countries?" European Journal of Development Research. Vol. 22 No. 3, pp.277-293.

Mooradian, T., Matzler, K., Uzelac, B. and Bauer, F. (2016), "Perspiration and inspiration: Grit and innovativeness as antecedents of entrepreneurial success", Journal of Economic Psychology, 56, pp.232-243.

Moira, R. (2002), “The Pierian spring, August 20-29, 2000", Women \& Performance: A Journal of Feminist Theory Vol.12 No. 2, pp.175-182.

Moulick, A.G., Pidduck, R.J. and Busenitz, L.W., 2019. Bloom where planted: Entrepreneurial catalyzers amidst weak institutions. Journal of Business Venturing Insights, Vol. 11, p.e00127. doi.org/10.1016/j.jbvi.2019.e00127

Murnieks, C.Y., Cardon, M.S., Sudek, R., White, T.D. and Brooks, W.T. (2016), “Drawn to the fire: The role of passion, tenacity and inspirational leadership in angel investing", Journal of Business Venturing, Vol. 31 No. 4, pp.468-484.

Nair, S. R. (2020), "The link between women entrepreneurship, innovation, and stakeholder engagement: A review. Journal of Business Research", Vol. 119, pp. 283-290.

Neumeyer, X., Santos, S.C., Caetano, A. and Kalbfleisch, P. (2019), "Entrepreneurship ecosystems and women entrepreneurs: A social capital and network approach", Small Business Economics, Vol. 53 No.2, pp.475-489.

Nwagu, N. B., \& Enofe, E. E. (2021), "The impact of entrepreneurship on the economic growth of an economy: An overview", Journal of Emerging Trends in Economics and Management Sciences Vol. 12 No.4, pp. 143-149.

Nziku, D.M. and Struthers, J.J. (2018), "Female entrepreneurship in Africa: Strength of weak ties in mitigating principal-agent problems", Journal of Small Business and Enterprise Development, Vol. 25 No. 3, pp. 349-367. 
Obisesan, O.O. and Olayide, O.E. (2021), "Asymmetric information, business environment, and transactions costs among business owners in Nigeria: Implications for female entrepreneurial sustainability transitions", Business Strategy \& Development, Vol. 4 No.1, pp.34-40.

Ojong, N., Simba, A., \& Dana, L. P. (2021), "Female entrepreneurship in Africa: A review, trends, and future research directions," Journal of Business Research, Vol. 132, pp.233-248.

Omeje, A.N., Jideofor, A. and Ugwu, M.O. (2020). Youth Empowerment and Entrepreneurship in Nigeria: Implication for Economic Diversification. SAGE Open, 10(4), p.2158244020982996.

Orser, B., Riding, A. and Stanley, J. (2012), "Perceived career challenges and response strategies of women in the advanced technology sector", Entrepreneurship \& Regional Development, Vol. 24 No.1-2, pp.73-93.

Ozasir Kacar, S. and Essers, C. (2019), "The interplay between identity construction and opportunity structures: Narratives of Turkish migrant women entrepreneurs in the Netherlands" International Small Business Journal, Vol. 37 No.7, pp.713-731.

Panda, S. (2018), "Constraints faced by women entrepreneurs in developing countries: review and ranking", Gender in Management: An International Journal, Vol. 33 No. 4, pp. 315-331.

Penaluna, A., Penaluna, K. (2009), 'Creativity in business, business in creativity, transdisciplinary curricula as an enabling strategy in enterprise education?', Industry and Higher Education, Vol 23, No 3, pp 209-219.

Pérez-López, M.C., González-López, M.J. and Rodríguez-Ariza, L. (2019), “Applying the social cognitive model of career self-management to the entrepreneurial career decision: The role of exploratory and coping adaptive behaviours", Journal of Vocational Behavior, Vol. 112, pp.255269.

Rae, D. (2000), “Understanding entrepreneurial learning: a question of how?", International Journal of Entrepreneurial Behaviour \& Research. Vol. 6 No. 3, pp. 145-159.

Ratten, V., \& Jones, P. (2018), “Bringing Africa into Entrepreneurship Research”, Basingstoke: Springer; Palgrave Macmillan.

Reaves, B.B. (2008), "Entrepreneurial success: A phenomenological study of the characteristics of successful female entrepreneurs". PhD dissertation. University of Phoenix, US. Retrieved from Pro Quest (UMI 3338362) (accessed 05 October 2021).

Robb, A.M. and Watson, J. (2012), "Gender differences in firm performance: Evidence from new ventures in the United States", Journal of Business Venturing, Vol.27 No.5, pp.544-558.

Rocha, V., \& Van Praag, M. (2020), “Mind the gap: The role of gender in entrepreneurial career choice and social influence by founders", Strategic Management Journal, Vol. 41 No.5, 841-866.

Rosca, E., Agarwal, N. and Brem, A. (2020), “Women entrepreneurs as agents of change: A comparative analysis of social entrepreneurship processes in emerging markets" Technological Forecasting and Social Change, Vol. 157, p.120067.

Santos, F.J., Roomi, M.A. and Liñán, F. (2016), "About gender differences and the social environment in the development of entrepreneurial intentions". Journal of Small Business Management, Vol. 54 No.1, pp.49-66.

Sarpong, D., Maclean, M. and Alexander, E. (2013), “Organizing strategic foresight: A contextual practice of 'way finding'. Futures, Vol. 53, pp.33-41. 
Solano, G. and Rooks, G. (2018), "Social capital of entrepreneurs in a developing country: The effect of gender on access to and requests for resources. Social Networks, Vol. 54, pp.279-290.

Sorgner, A. (2015), "Non-cognitive skills, occupational choices, and entrepreneurship: an empirical analysis of entrepreneurs' career choices", International Journal of Entrepreneurship and Small Business, Vol. 25 No.2, pp.208-230.

Sullivan, D.M. and Meek, W.R. (2012), "Gender and entrepreneurship: a review and process model", Journal of Managerial Psychology, Vol. 27 No. 5, pp. 428-458.

Sun, S.L., Shi, W.S., Ahlstrom, D. and Tian, L.R. (2020), “Understanding institutions and entrepreneurship: The microfoundations lens and emerging economies", Asia Pacific Journal of Management Vol. 37 No.4 pp.957-979.

Tarling, C., Jones, P. and Murphy, L. (2016), "Influence of early exposure to family business experience on developing entrepreneurs", Education + Training, Vol. 58 No. 7/8. https://doi.org/10.1108/ET03-2016-0050.

Tlaiss, H.A. and McAdam, M. (2021), "Islam, Arab women's entrepreneurship and the construal of success", International Journal of Entrepreneurial Behavior \& Research, Vol. 27 No. 3, pp. 821-844.

Tlaiss, H. A. (2019),"Contextualizing the career success of Arab women entrepreneurs." Entrepreneurship E Regional Development Vol. 31, No. 3-4, pp. 226-241.

Tur-Porcar, A., Mas-Tur, A. and Belso, J.A. (2017). “Barriers to women entrepreneurship. Different methods, different results?" Quality \& Quantity, Vol. 51 No.5, pp.2019-2034.

Valdivia, M. (2015), "Business training plus for female entrepreneurship? Short and medium-term experimental evidence from Peru", Journal of Development Economics Vol.113, pp.33-51.

Van Auken, H., Fry, F.L. and Stephens, P. (2006), “The influence of role models on entrepreneurial intentions", Journal of Developmental Entrepreneurship, Vol. 11 No.2, pp.157-167.

VanderBrug, J. (2013), “The global rise of female entrepreneurs", available at: https://hbr.org/201 3/09/global-rise-of-female-entrepreneurs (accessed 30 September 2021).

Vracheva, V. and Stoyneva, I. (2020), "Does gender equality bridge or buffer the entrepreneurship gender gap? A cross-country investigation", International Journal of Entrepreneurial Behavior \& Research, Vol. 26 No. 8, pp. 1827-1844.

Waddock, S. and Steckler, E. (2016), “Visionaries and wayfinders: Deliberate and emergent pathways to vision in social entrepreneurship", Journal of Business Ethics, Vol. 133 No. 4, pp.719-734.

Ward, A., Hernández-Sánchez, B.R. and Sánchez-García, J.C. (2019). “Entrepreneurial potential and gender effects: the role of personality traits in university students' entrepreneurial intentions". Frontiers in Psychology, Vol 10, p.2700.

Wei, X., Liu, X. and Sha, J. (2019), "How does the entrepreneurship education influence the students' innovation? Testing on the multiple mediation model", Frontiers in Psychology, 10, p.1557. https://doi.org/10.3389/fpsyg.2019.01557

Welter, F., Baker, T. and Wirsching, K., (2019), "Three waves and counting: the rising tide of contextualization in entrepreneurship research. Small Business Economics, Vol. 52 No.2, pp.319330 .

Welter, F. (2011), "Contextualizing entrepreneurship-conceptual challenges and ways forward", Entrepreneurship Theory and Practice, Vol. 35 No.1, pp.165-184. 
Westhead, P., \& Solesvik, M. Z. (2016), “Entrepreneurship education and entrepreneurial intention: Do female students benefit?" International Small Business Journal, Vol. 34 No.8, pp.979-1003.

Wheadon, M. and Duval-Couetil, N. (2019), “Token entrepreneurs: A review of gender, capital, and context in technology entrepreneurship", Entrepreneurship \& Regional Development, Vol. 31 No. 3-4, pp.308-336.

Wu, Z.A. (2012). "Second-order gender effects: the case of US small business borrowing cost", Entrepreneurship Theory and Practice, Vol. 36 No. 3, pp. 443-463.

Wu, J. and Sirgy, M.J. (2014), “Do purchasing managers discriminate against supply firms owned and run by women?" Journal of Small Business E Entrepreneurship, Vol. 27 No. 1, pp.67-88.

Yetim, N (2008), "Social capital in female entrepreneurship", International Sociology, Vol. 23 No.6, pp. 864-885.

Zaman, S., Arshad, M., Sultana, N. and Saleem, S. (2021), "The effect of family business exposure on individuals' entrepreneurial intentions: an institutional theory perspective", Journal of Family Business Management, Vol. 11 No. 4, pp. 368-385.

Zapkau, F.B., Schwens, C., Steinmetz, H. and Kabst, R. (2015). "Disentangling the effect of prior entrepreneurial exposure on entrepreneurial intention". Journal of Business Research, Vol. 68 No.3, pp.639-653.

Zhao, H., O'Connor, G., Wu, J. and Lumpkin, G.T., 2021. Age and entrepreneurial career success: A review and a meta-analysis", Journal of Business Venturing, Vol.36 No.1 pp.1-20.

Zikic, J. and Ezzedeen, S. (2015), "Towards a more integrated view of entrepreneurial careers: Qualitative investigation of the three forms of career capital and their relationships among high tech entrepreneurs", International Journal of Entrepreneurial Behavior \& Research, Vol. 21 No. 6, pp. 756-777. 
Table 1: Biographical sketch of entrepreneurs

\begin{tabular}{|c|c|c|c|c|c|c|c|}
\hline No & Pseudonym & Age & Venture Type & Nature of business (SIC)* & $\begin{array}{c}\text { No. } \\
\text { Employees }\end{array}$ & $\begin{array}{l}\text { Published } \\
\text { Date }\end{array}$ & $\begin{array}{c}\text { YouTube } \\
\text { views to Date }\end{array}$ \\
\hline 1 & Agnes & 34 & Architecture & 71111 Architectural activities & $45+$ & 06.04 .2020 & $4.3 \mathrm{~K}+$ \\
\hline 2 & Ava & 40 & Real Estate & 68100 Buying and selling of own real estate & $13+$ & 08.04 .2020 & $1.4 \mathrm{~K}+$ \\
\hline 3 & Amelia & 37 & Destination Management & 79110 Travel agency activities & $7+$ & 18.04 .2020 & $400+$ \\
\hline 4 & Beatrice & 37 & Marketing \& Comms & 73110 Advertising agencies & $10+$ & 20.04 .2020 & $550+$ \\
\hline 5 & Charlotte & 36 & Skill Development & 85590 Other education n.e.c. & $25+$ & 24.04 .2020 & $2.7 \mathrm{~K}+$ \\
\hline 6 & Daisy & 33 & E-Commerce & $\begin{array}{l}46160 \text { Agents involved in the sale of textiles, clothing, fur, } \\
\text { footwear, and leather goods }\end{array}$ & $20+$ & 28.04 .2020 & $950+$ \\
\hline 7 & Emma & 35 & Branding and Marketing & 73110 Advertising agencies & $10+$ & 30.042020 & $650+$ \\
\hline 8 & Fran & 40 & Design & 74100 Specialized design activities & $10+$ & 02.05 .2020 & $1.3 \mathrm{~K}+$ \\
\hline 9 & Grace & 26 & Finance & 64921 Credit granting by non-deposit taking finance houses & $154+$ & 04.05 .2020 & $540+$ \\
\hline 10 & Helen & 35 & Philanthropy & 88990 Other social work activities without accommodation & $26+$ & 07.05 .2020 & $730+$ \\
\hline 11 & Isabella & 37 & Waste Management & $\begin{array}{l}39000 \text { Remediation activities and other waste management } \\
\text { services }\end{array}$ & $120+$ & 26.05 .2020 & $750+$ \\
\hline 12 & Laura & 40 & Entertainment & 9234 Other entertainment activities & $11+$ & 27.07 .2020 & $2.1 \mathrm{~K}+$ \\
\hline 13 & Mia & 38 & Events & 56210 Event catering activities & $10+$ & 31.08 .2020 & $865+$ \\
\hline 14 & Olivia & 39 & Experiential Marketing & 73110 Advertising agencies & $5+$ & 21.09 .2020 & $327+$ \\
\hline 15 & Pam & 39 & Fashion / Beauty & 96020 Hairdressing and other beauty treatment & $30+$ & 05.10 .2020 & $940+$ \\
\hline 16 & Rose & 35 & Healthcare & 86900 Other human health activities & $10+$ & 19.10.2020 & $915+$ \\
\hline 17 & Sophia & 36 & Visual Arts & 90040 Operation of arts facilities & $36+$ & 02.11 .2020 & $480+$ \\
\hline 18 & Taга & 35 & Education & 85590 Other education n.e.c. & $45+$ & 27.12 .2020 & $245+$ \\
\hline 19 & Winnie & 23 & Fashion & 47710 Retail sale of clothing in specialized stores & $20+$ & 31.01 .2021 & $304+$ \\
\hline 20 & Yvonne & 40 & Retail & 47190 Other retail sale in non-specialized stores & $11+$ & 15.03.2021 & $549+$ \\
\hline
\end{tabular}

*A SIC code is a Standard Industrial Classification code used by the UK Companies House to classify the type of economic activity in which a company or other type of business is engaged. 
Table 2: Dimensions, themes, meanings, and data

\section{Second-order themes \\ 1 Aggregate dimension: 'Observing and playing business' \\ - Early commitment to enterprise \\ - Strong positive emotional arousal with enterprise related activities}

2 Aggregate dimension: Traipsing the 'path less travelled'

- contrarian vision for something new - opportunity recognition in real time

3 Aggregate dimension: A hook to the 'pierian spring' of entrepreneurship

- Personal efficacy and foresight

- Commitment to long life education

4 Aggregate dimension: 'Grace under pressure' in decision making

- Having nothing to lose mentality

- Resilience, grit, and courage to taking moderate and calculated risk

\section{Meanings highlighting the becoming}

of successful entrepreneurial careers

Representative data

Early career entrepreneurial accomplishment in late childhood, teenage years, and early adulthood.

Spotting opportunities worth pursuing, and developing foresight and a capacity to focus

Quest for new knowledge and continuous learning to starting, growing, and managing ventures

Courage to engaging and making good decisions when faced with complex and multifaceted problems within the contingencies of organizing
- I asked myself, how do I make that extra money in school? I started going to get fabrics, you know make them, sell them in school, so that was how my fashion business started. (Ava)

- I started running the business at the age of 17 , that was before I was to university. (Fran)

- It is very important for me as CEO to continue to reinvent myself. You must be knowledgeable about whatever it is you're doing. (Beatrice)

- You must ensure that people buy into the vision and the cause. There's no point saying that the people are in need in the communities if the communities themselves don't think they're in need. (Helen)

- I got admitted into an accelerator at MIT so for the summer we spent quite a bit of time just walking through the idea and setting up the business. They gave us the confidence and the skill set that we needed to start-up. (Isabella)

- I did a minor in entrepreneurship at university, and I realised I could turn my passion into profit. (Emma)

- What Lagos does is it makes you rethink your vision. You've got to have some sort of energy, resilience, doggedness to truly succeed in the city of Lagos. (Fran)

- Trust me, most of us wouldn't even make it in this business if we were not diehards. I got myself there, I had to work for it, I had to sweat for it, I had to create the opportunities for myself. (Pam) 
Figure 1 Careers of successful female entrepreneur as played out in context of weak institutions and underdeveloped markets

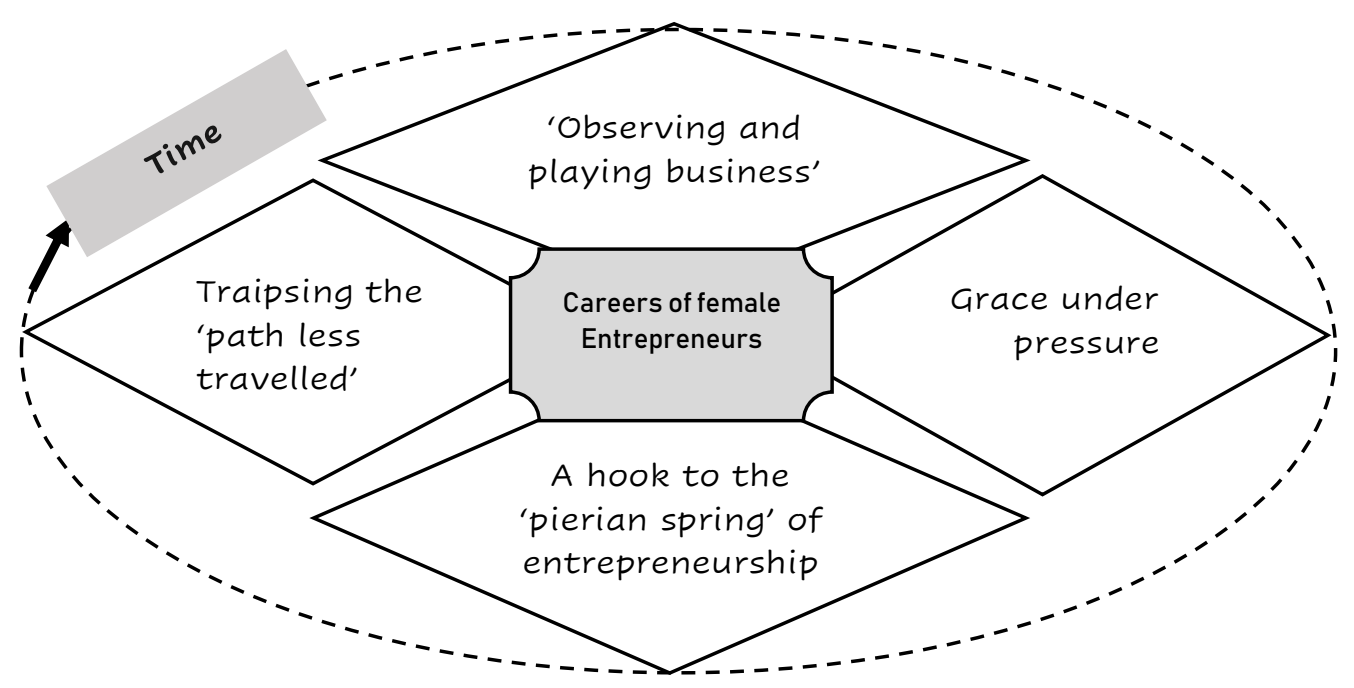

